\title{
Experimental Research on Fire Resistance of Reactive Powder Concrete
}

\author{
Gai-Fei Peng, Yi-Rong Kang, Yan-Zhu Huang, Xiao-Ping Liu, and Qiang Chen
}

Faculty of Civil Engineering \& Architecture, Beijing Jiaotong University, Beijing 100044, China

Correspondence should be addressed to Gai-Fei Peng, gfpeng@bjtu.edu.cn

Received 18 November 2011; Accepted 22 February 2012

Academic Editor: Jin Ping Lu

Copyright () 2012 Gai-Fei Peng et al. This is an open access article distributed under the Creative Commons Attribution License, which permits unrestricted use, distribution, and reproduction in any medium, provided the original work is properly cited.

\begin{abstract}
An experimental investigation was conducted on fire resistance of reactive powder concrete (RPC), mainly on explosive spalling occurrence and residual mechanical properties exposed to high temperature. The residual mechanical properties measured include compressive strength, tensile splitting strength, and fracture energy. RPC was prepared using cement, sand, silica fume, steel fiber, and polypropylene fiber. After subjected to high temperatures from 200 to $600^{\circ} \mathrm{C}$, the residual mechanical properties were determined. RPC spalled considerably under high temperature. After exposure to high temperatures from 200 to $400^{\circ} \mathrm{C}$, mechanical properties were enhanced more or less, which can be attributed to further hydration of cementitious materials activated by elevated temperature. Compressive strength started to decrease after exposure to $400^{\circ} \mathrm{C}$, but tensile splitting strength and fracture energy started to decrease after exposure to $200^{\circ} \mathrm{C}$. Incorporating hybrid fiber (polypropylene fiber and steel fiber) is a promising way to enhance resistance of RPC to explosive spalling, which should be a main objective for improving its fire resistance.
\end{abstract}

\section{Introduction}

As a new generation of concrete, reactive powder concrete (RPC) has attracted great research attention for its ultrahigh strength and high durability $[1,2]$. In general, RPC is characterized by very low water/binder (W/B) ratio below 0.20 , and very dense microstructure formed by using a series of powders including cement, silica fume, and ground quartz sand. Cured under hot water condition, RPC may have compressive strength between 100 and $800 \mathrm{MPa}$.

To a variety of applications of RPC, such as prestressed concrete structures, nuclear power stations, large-span archroof structures, and bridges, fire is still a potential risk. However, so far there are only a few reports on fire resistance or fire behavior of RPC, and experimental data are especially lacked for evaluating fire resistance of RPC. Since 2000, a couple of investigations by means of computer modeling revealed that RPC is prone to explosive spalling under high temperature [3-5]. Moreover, an experimental investigation in 2009 [6] found that RPC spalled under high temperature, in a manner as layer by layer when column specimens were used, which was quite different from that of high-strength or high-performance concrete reported in most literature. But the mechanism for spalling behavior of RPC remains unknown. Furthermore, mechanical properties including strength and fracture energy of RPC exposed to high temperature are also of great concern.

In the present paper, an experimental investigation was conducted on explosive spalling and mechanical properties of RPC subjected to high temperature. The effects of W/B ratio, moisture content, and fiber are discussed.

\section{Experimental Details}

2.1. General. RPC were prepared using polypropylene fibers, steel fibers, and combinations of the two types of fibers. Specimens in the forms of $100 \mathrm{~mm} \times 100 \mathrm{~mm} \times$ $100 \mathrm{~mm}$ cubes and $100 \mathrm{~mm} \times 100 \mathrm{~mm} \times 300 \mathrm{~mm}$ beams were of eight types of concrete designated by $0.16 \mathrm{~S}_{2.0}$, $0.18 \mathrm{~S}_{2.0}, 0.18 \mathrm{P}_{0.10} \mathrm{~S}_{2.0}, \quad 0.18 \mathrm{P}_{0.15} \mathrm{~S}_{2.0}, \quad 0.18 \mathrm{P}_{0.20} \mathrm{~S}_{2.0}, 0.20 \mathrm{~S}_{2.0}$, $0.16 \mathrm{P}_{0.15} \mathrm{~S}_{2.0}$, and $0.20 \mathrm{P}_{0.15} \mathrm{~S}_{2.0}$. Their mix proportions and compressive strength at 28 days are given in Table 1 . The diameter and length of the polypropylene fiber (PP fiber) 
TABLE 1: Mix proportions and compressive strength of RPC tested.

\begin{tabular}{|c|c|c|c|c|c|c|c|c|c|}
\hline \multirow{2}{*}{ No. } & \multirow{2}{*}{ Type of RPC } & \multirow{2}{*}{$\mathrm{W} / \mathrm{B}$} & \multicolumn{6}{|c|}{ Quantity $\left(\mathrm{kg} / \mathrm{m}^{3}\right)$} & \multirow{2}{*}{ 28d strength $(\mathrm{MPa})$} \\
\hline & & & Cement & Water & Sand & Silica fume & Steel fiber & PP fiber & \\
\hline (1) & $0.16 \mathrm{~S}_{2.0}$ & 0.16 & 720 & 144 & 1166 & 180 & 156 & 0 & 105.3 \\
\hline (2) & $0.18 \mathrm{~S}_{2.0}$ & 0.18 & 720 & 162 & 1080 & 180 & 156 & 0 & 80.8 \\
\hline (3) & $0.18 \mathrm{P}_{0.10} \mathrm{~S}_{2.0}$ & 0.18 & 720 & 162 & 1080 & 180 & 156 & 0.91 & 90.2 \\
\hline (4) & $0.18 \mathrm{P}_{0.15} \mathrm{~S}_{2.0}$ & 0.18 & 720 & 162 & 1080 & 180 & 156 & 1.37 & 95.6 \\
\hline (5) & $0.18 \mathrm{P}_{0.20} \mathrm{~S}_{2.0}$ & 0.18 & 720 & 162 & 1080 & 180 & 156 & 1.82 & 80.9 \\
\hline (6) & $0.20 S_{2.0}$ & 0.20 & 720 & 180 & 1166 & 180 & 156 & 0 & 86.3 \\
\hline (7) & $0.16 \mathrm{P}_{0.15} \mathrm{~S}_{2.0}$ & 0.16 & 720 & 144 & 1166 & 180 & 156 & 1.37 & 97.9 \\
\hline$(8)$ & $0.20 \mathrm{P}_{0.15} \mathrm{~S}_{2.0}$ & 0.20 & 720 & 180 & 1166 & 180 & 156 & 1.37 & 70.2 \\
\hline
\end{tabular}

were $20 \mu \mathrm{m}$ and $20 \mathrm{~mm}$, while the diameter and length of steel fiber were $0.22 \mathrm{~mm}$ and $13 \mathrm{~mm}$. Fine aggregate of quartz sand with fineness of 1.3 and ordinary Portland cement of $42.5 \mathrm{MPa}$ grade were employed. Polycarboxylate superplasticizer was used to maintain slump of mixtures from $100 \mathrm{~mm}$ to $190 \mathrm{~mm}$.

After demolding at one day, the specimens were cured in hot water at $90^{\circ} \mathrm{C}$ for three days and then in water at $20^{\circ} \mathrm{C}$ until being tested.

2.2. Explosive Spalling Test. Spalling tests were conducted on cubes of $100 \mathrm{~mm} \times 100 \mathrm{~mm} \times 100 \mathrm{~mm}$ of six types of RPC, from no. 1 to no. 6 in Table 1, at age between 40 days and 50 days. Specimens were heated in an electric furnace at a rate of $10^{\circ} \mathrm{C} / \mathrm{min}$. The heating rate was measured in the air at a position approximately $4 \mathrm{~cm}$ above the upper surface of a concrete specimen inside the electric furnace. This rate was the same as in heating for the determinations of strength and fracture energy. The temperature-time curve of the spalling tests with a target temperature of $700^{\circ} \mathrm{C}$ is given in Figure 1. The target temperature was maintained for $1 \mathrm{hr}$. It was estimated, according to test results in a previous investigation [7], that temperature at the center of a specimen rose gradually to the target temperature from the first 20th minute during the $1 \mathrm{hr}$ period for maintaining temperature, which was then maintained for the remaining 40 minutes until electric heating was turned off.

2.3. Determination of Strength. Cube specimens of $100 \mathrm{~mm}$ size of three types of RPC, that is, No. 4, No. 7, and No. 8 in Table 1, were employed for strength determination. At 28 days three specimens for each batch were taken out from curing water and dried at $105^{\circ} \mathrm{C}$ for about two days, in order to decrease moisture content of concrete to a lower degree, so that the specimens for strength determination would not encounter explosive spalling when exposed to heating [8]. The specimens were then heated in an electric furnace to temperatures of 200,400 , and $600^{\circ} \mathrm{C}$, respectively, at a heating rate of $10^{\circ} \mathrm{C} / \mathrm{min}$, as shown in Figure 1 . The target temperatures were maintained for $1 \mathrm{hr}$. After the specimens had been allowed to cool naturally to room temperature, the residual mechanical properties were determined including compressive strength and tensile splitting strength after two days from heating. Determination of compressive strength

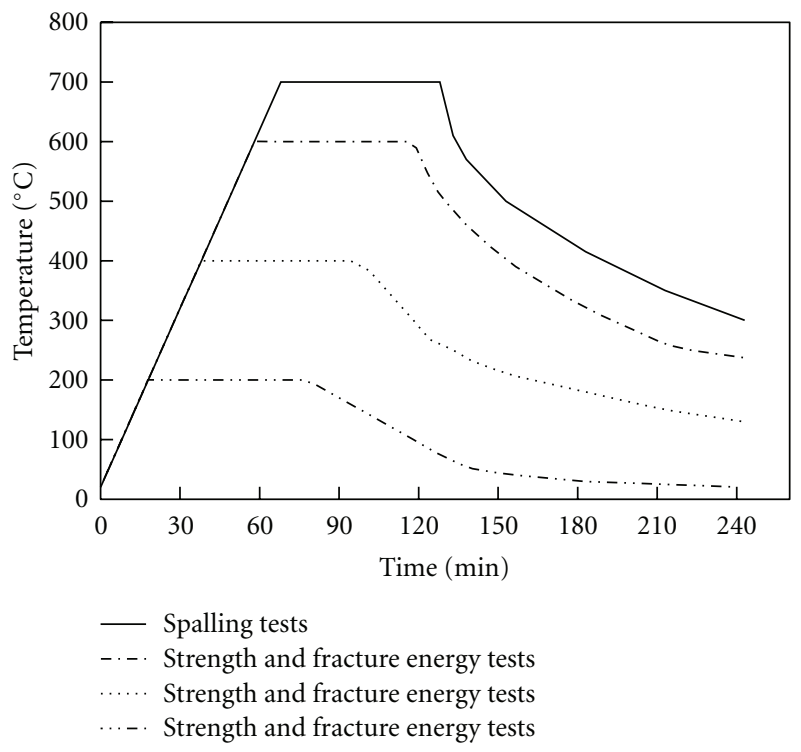

Figure 1: Temperature-time curves in heating of spalling test specimens.

and tensile splitting strength was according to the China standard GBJ 81-85 [9] which is similar to BS 1881:Part 116.

2.4. Determination of Fracture Energy. Notched beam specimens of $100 \mathrm{~mm} \times 100 \mathrm{~mm} \times 300 \mathrm{~mm}$ of the same three types of RPC as in Section 2.3 were employed for fracture energy determination. At 28 days three specimens for each batch were exposed to $105^{\circ} \mathrm{C}$ for two days, and then heated to temperature of $400^{\circ} \mathrm{C}$ at a heating rate of $10^{\circ} \mathrm{C} / \mathrm{min}$. The target temperature was maintained for $1 \mathrm{~h}$. After the specimens cooled naturally to room temperature, the residual fracture energy was determined. Fracture energy was determined according to a RILEM test method [10].

A notch was prepared on each beam specimen during casting, to form a crack at the midspan of each specimen prior to heating [8]. In a three-point bending test on a beam specimen, mid-span deflection $\delta$ was recorded during the whole loading process until failure. The loading was in a displacement-controlled manner at a rate of $0.05 \mathrm{~mm} / \mathrm{min}$. From a load-deflection curve recorded, the fracture energy 
TABLE 2: Statistical results of explosive spalling tests on RPC with various moisture contents.

\begin{tabular}{lccccccc}
\hline Type of RPC & \multicolumn{7}{c}{ Moisture content } \\
\hline $0.16 \mathrm{~S}_{2.0}$ & $3(3)$ & $3(3)$ & $30 \%$ & $63 \%$ & $75 \%$ & $88 \%$ \\
$0.18 \mathrm{~S}_{2.0}$ & $3(0)$ & $3(3)$ & $3(3)$ & $3(3)$ & $3(3)$ & $3(3)$ & $3(3)$ \\
$0.18 \mathrm{P}_{0.10} \mathrm{~S}_{2.0}$ & $3(0)$ & $3(2)$ & $3(3)$ & $3(3)$ & $3(3)$ & $3(3)$ & $3(3)$ \\
$0.18 \mathrm{P}_{0.15} \mathrm{~S}_{2.0}$ & $3(0)$ & $3(0)$ & $3(1)$ & $3(2)$ & $3(3)$ & $3(3)$ & $3(3)$ \\
$0.18 \mathrm{P}_{0.20} \mathrm{~S}_{2.0}$ & $3(0)$ & $3(1)$ & $3(3)$ & $3(3)$ & $3(3)$ & $3(3)$ \\
$0.20 \mathrm{~S}_{2.0}$ & $3(0)$ & $3(0)$ & $3(2)$ & $3(3)$ & $3(3)$ & $3(3)$ \\
\hline
\end{tabular}

* Note: the value outside the bracket was the total number of specimens tested in a given batch, while the value in the bracket was the number of specimens encountered spalling in this batch.

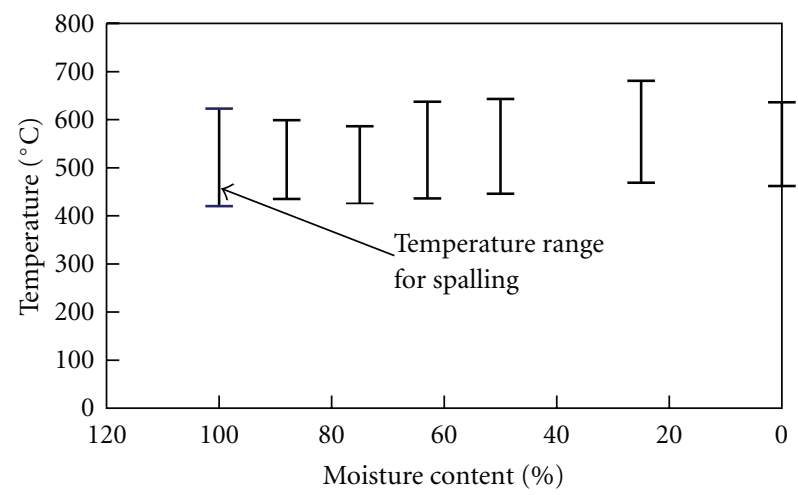

(a) $0.16 \mathrm{~S}_{2.0}$

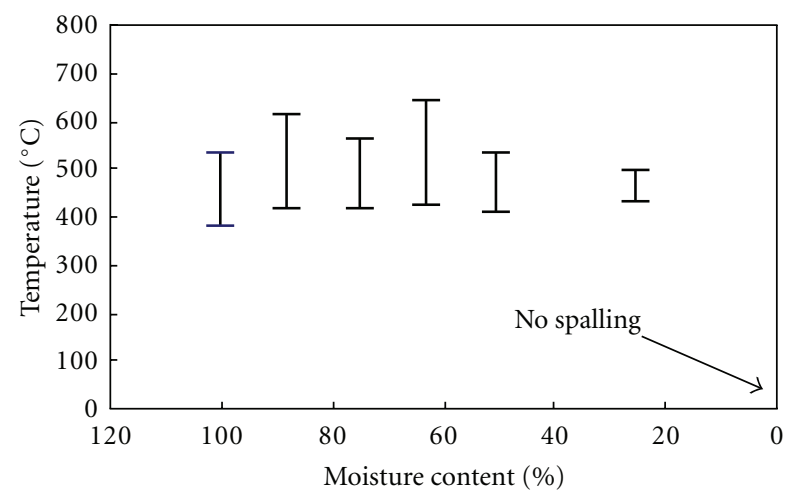

(b) $0.18 \mathrm{P}_{0.10} \mathrm{~S}_{2.0}$

FIGURE 2: Temperature range for spalling of two types of RPC with various moisture contents.

of concrete could be calculated by using (1) that is specified in the RILEM method [10]. We have

$$
G_{F}=\frac{\left[\int_{0}^{\delta_{0}} P(\delta) d \delta+m g \delta_{0}\right]}{A_{\text {lig }}},
$$

where $G_{F}=$ the fracture energy $\left(\mathrm{J} / \mathrm{m}^{2}\right), m=m_{1}+m_{2}(\mathrm{~kg})$, $m_{1}=M \times s / L$ (weight of the beam between the support, calculated as the beam weight multiplied by $s / L$ ), $M=$ mass of the specimen, $m_{2}=$ weight of the part of the loading arrangement which is not attached to the machine but follows the beam until failure, $s=$ span, $L=$ length of the specimen, $g=9.81 \mathrm{~m} / \mathrm{s}^{2}, \delta_{0}=$ the mid-span deflection of the specimen at failure (m), $A_{\text {lig }}=$ area of the ligament $\left(\mathrm{m}^{2}\right), \delta=$ mid-span deflection $(\mathrm{m})$, and $P=\operatorname{load}(\mathrm{N})$.

\section{Results and Discussion}

3.1. Explosive Spalling. The statistical results of the spalling tests are given in Table 2. Among the six types of RPC, RPC at a lower $\mathrm{W} / \mathrm{B}$ ratio suffered greater spalling damage, in terms of greater spalling occurrence frequency in Table 2. For RPC at a $\mathrm{W} / \mathrm{B}$ ratio of $0.16\left(0.16 \mathrm{~S}_{2.0}\right)$, spalling occurred within temperature range shown in Figure 2(a) under all moisture contents, while RPC at a W/B ratio of $0.20\left(0.20 S_{2.0}\right)$ did not spall under low moisture content ranged from $0 \%$ to $25 \%$. Therefore, for obtaining ultra-high mechanical properties, RPC usually has a low W/B ratio below 0.20 and hence is highly prone to explosive spalling under high temperature.
It can also be seen in Table 2 that fibers including steel fiber and polypropylene (PP) fiber have a positive effect on inhibiting explosive spalling of RPC. As a reinforcing fiber, steel fiber which is usually employed in RPC at 0.18 and $0.20 \mathrm{~W} / \mathrm{B}$ ratios could avoid spalling under low moisture contents, as shown in Figure 2(b). It has been commonly recognized that PP fiber has a positive effect on inhibiting explosive spalling of concrete, as shown in Table 2. However, in the present research, PP fiber could not avoid spalling under relatively high moisture contents ranged from $25 \%$ to $100 \%$, which is different from the effect of PP fiber on explosive spalling of high-strength or high-performance concrete at strength grade below $100 \mathrm{MPa}$ reported previously [8]. Nevertheless, incorporating hybrid fiber (polypropylene fiber and steel fiber) is a promising way to enhance resistance of RPC to explosive spalling, which should be a main objective for improving its fire resistance and needs further research.

The results of observations of two typical types of RPC with various moisture contents after spalling tests are given in Table 3. It is obvious that, the higher the moisture content, the greater the degree of spalling occurrence, which means that more broken pieces were formed by spalling of a cube specimen. Under high moisture contents such as $100 \%$ and $88 \%$, concrete fully spalled and broken into small pieces, while, under low moisture contents, the results are quite different, such as $0 \%$, RPC of $0.16 \mathrm{~S}_{2.0}$ (only partially spalled) and RPC of $0.18 \mathrm{P}_{0.10} \mathrm{~S}_{2.0}$ (no spalling). 
TABLE 3: Observations of two types of RPC with various moisture contents after spalling tests.

\begin{tabular}{|c|c|c|c|c|}
\hline \multirow{2}{*}{$\begin{array}{l}\text { Moisture } \\
\text { content }\end{array}$} & \multicolumn{2}{|c|}{$0.16 \mathrm{~S}_{2.0}$} & \multicolumn{2}{|r|}{$0.18 \mathrm{P}_{0.10} \mathrm{~S}_{2.0}$} \\
\hline & Observation & Brief description & Observation & Brief description \\
\hline $100 \%$ & & $\begin{array}{l}\text { A cube fully spalled and } \\
\text { broke into small pieces. }\end{array}$ & & $\begin{array}{l}\text { A cube fully spalled and broke into } \\
\text { small pieces. }\end{array}$ \\
\hline $88 \%$ & & $\begin{array}{l}\text { A cube fully spalled and } \\
\text { broke into small pieces. }\end{array}$ & & $\begin{array}{l}\text { A cube fully spalled and broke into } \\
\text { small pieces. }\end{array}$ \\
\hline $75 \%$ & & $\begin{array}{l}\text { A cube fully spalled and } \\
\text { broke into small pieces. }\end{array}$ & & $\begin{array}{l}\text { A cube spalled and broke into small } \\
\text { and large pieces. }\end{array}$ \\
\hline $63 \%$ & & $\begin{array}{l}\text { A cube fully spalled and } \\
\text { broke into small or large } \\
\text { pieces. }\end{array}$ & & A cube partially spalled. \\
\hline $50 \%$ & & $\begin{array}{l}\text { A cube fully spalled and } \\
\text { broke into large pieces. }\end{array}$ & & A cube partially spalled. \\
\hline $25 \%$ & & $\begin{array}{l}\text { A cube fully spalled and } \\
\text { broke into large pieces. }\end{array}$ & & \\
\hline & & & & A cube remained intact (no spalling). \\
\hline $0 \%$ & & A cube partially spalled. & & A cube remained intact (no spalling). \\
\hline
\end{tabular}

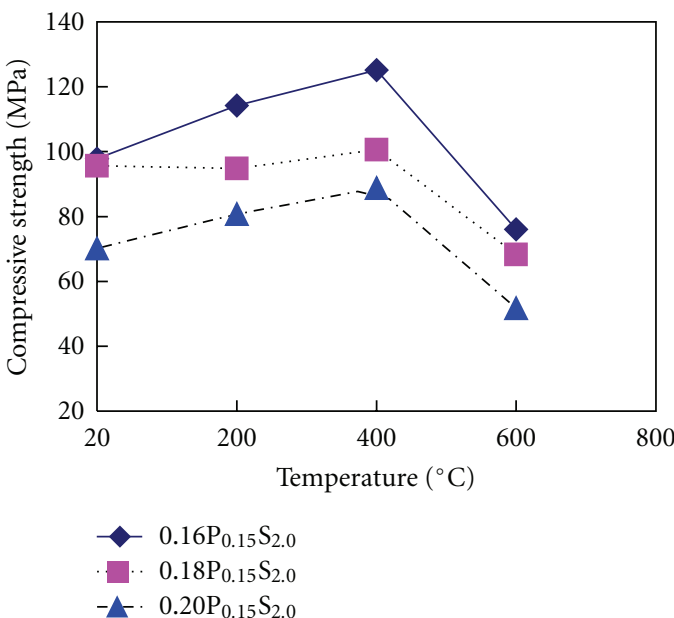

(a) Residual compressive strength

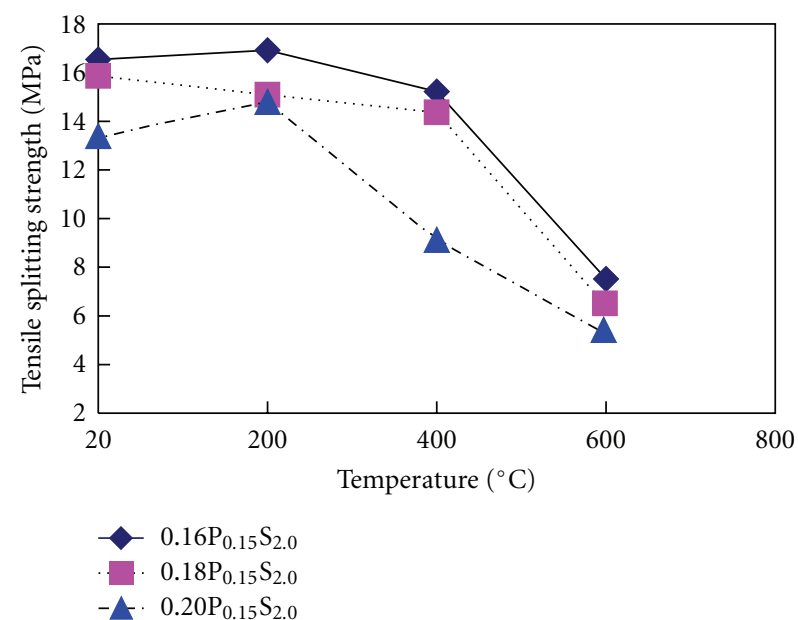

(b) Residual splitting strength

FIgURE 3: Residual strength of RPC with different W/B ratios. 


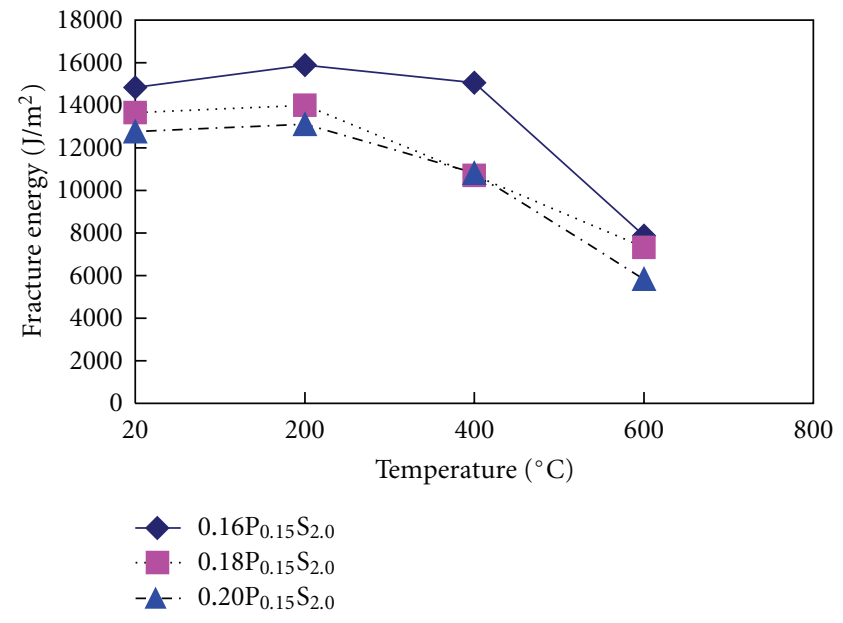

FIgURE 4: Residual fracture energy of RPC with different W/B ratios.

3.2. Strength. The results of compressive strength and tensile splitting strength of RPC are given in Figures 3(a) and 3(b), respectively. Each point in Figures 3(a) and 3(b) was obtained from the average of tests on three cubes a batch. Figure 3(a) shows that high temperatures can be divided into two ranges in terms of effect on RPC's strength loss, namely, $20-400^{\circ} \mathrm{C}$ and $400-600^{\circ} \mathrm{C}$. In the range $20-400^{\circ} \mathrm{C}$, the three types of RPC maintained or even got an increase in their original strength. In the range $400-600^{\circ} \mathrm{C}$, these RPCs lost their original strength considerably. Thus, the range $400-600^{\circ} \mathrm{C}$ may also be regarded as the critical temperature range for the strength loss of RPC, which is similar to that of plain or fiber concrete with strength grade below $100 \mathrm{MPa}$ [8]. Compared with previous knowledge [8, 11], the increase in compressive strength in the range $20-400^{\circ} \mathrm{C}$ in this investigation might be due to further hydration of cement residues or reaction between calcium hydroxide and minerals such as silica fume. But the mechanism for such an increase in compressive strength needs further research.

The loss in tensile splitting strength in Figure 3(b) was considerable in the range $200-600^{\circ} \mathrm{C}$, which was clearly different from the change in compressive strength, that is increased in the range $20-400^{\circ} \mathrm{C}$ and then gradually decreased in the range $400-600^{\circ} \mathrm{C}$. This is because tensile strength is more sensitive to flaws either on macro- or on microscale which are caused by high temperatures to concrete [11], such as thermal cracking or melting of PP fiber and formation of interconnected pores.

3.3. Fracture Energy. The results of residual fracture energy of RPC after exposure to $400^{\circ} \mathrm{C}$ are given in Figure 4. As a whole, RPC had much higher fracture energy (12700$\left.14800 \mathrm{~J} / \mathrm{m}^{2}\right)$ than that of plain concrete $\left(100-250 \mathrm{~J} / \mathrm{m}^{2}\right)$ [8]. Under $200^{\circ} \mathrm{C}$, fracture energy increased slightly, but decreased under $400^{\circ} \mathrm{C}$ and $600^{\circ} \mathrm{C}$. In spite of such a decrease, fracture energy of RPC after exposure to $600^{\circ} \mathrm{C}$ was still as high as $5800-7800 \mathrm{~J} / \mathrm{m}^{2}$. It is estimated that the bonding force of hardened cement paste at a very low
$\mathrm{W} / \mathrm{B}$ ratio is so high that a more pronounced fiber pullout process can take place during fracture of RPC after heating. The increase in fracture energy of RPC after exposure to $200^{\circ} \mathrm{C}$ can be correlated to further hydration of cementitious materials, while the decrease in fracture energy of RPC after exposure to $400^{\circ} \mathrm{C}$ and $600^{\circ} \mathrm{C}$ can be attributed to thermal cracking, formation of interconnected pores, and porestructure coarsening [11].

\section{Conclusions}

Based on the experimental results in this research, the following conclusions can be drawn.

(i) $\mathrm{RPC}$ at a low $\mathrm{W} / \mathrm{B}$ ratio from 0.16 to 0.20 is highly prone to explosive spalling under high temperature. PP fiber has a slightly positive effect on inhibiting explosive spalling RPC, which is not as efficient as in high-strength or high-performance concrete.

(ii) Under high moisture contents, RPC fully spalled and broke into small pieces, while, under low moisture contents, RPC only partially spalled or experienced no spalling.

(iii) High temperatures can be divided into two ranges in terms of strength loss in RPC, namely, 200$400^{\circ} \mathrm{C}$ and $400-600^{\circ} \mathrm{C}$. In the range $200-400^{\circ} \mathrm{C}, \mathrm{RPC}$ maintained or even got an increase in their original strength, for which the reason is unclear and needs further research. In the range $400-600^{\circ} \mathrm{C}$, RPC lost their original strength considerably.

(iv) As a whole, RPC had much higher fracture energy than that of plain concrete. Moreover, fracture energy of RPC after exposure to $600^{\circ} \mathrm{C}$ was still quite high. The reason may be that the bonding force of hardened cement paste in RPC is so high that a more pronounced fiber pullout process can take place during fracture of RPC after heating.

\section{Acknowledgments}

The authors gratefully acknowledge the financial support of the National Science Foundation of China (Project no.: 50978026) and the China Ministry of Education (Project no.: 20100009110014). Shanghai Bekaert-Ergang Company Ltd. is also acknowledged for providing steel fiber.

\section{References}

[1] M. Cheyrezy, V. Maret, and L. Frouin, "Microstructural analysis of RPC (reactive powder concrete)," Cement and Concrete Research, vol. 25, no. 7, pp. 1491-1500, 1995.

[2] O. Bonneau, C. Poulin, J. Dugat, P. Richard, and P. C. Aitcin, "Reactive powder concretes: from theory to practice," Concrete International, vol. 18, no. 4, pp. 47-49, 1996.

[3] U. Schneider, U. Diederichs, J. Horvath et al., "Verhalten von Ultrahochfesten Betonen (UHPC) unter randbeanspruchung (Behaviour of Ultra High Performance Concrete (UHPC) under fire exposure)," Beton- und Stahlbetonbau, vol. 98, no. 7, pp. 408-417, 2003. 
[4] C. E. Majorana and F. Pesavento, "Damage and spalling in HP and UHF concrete at high temperature," in Damage and Fracture Mechanics VI: Computer Aided Assessment and Control, vol. 6 of Structures and Materials, pp. 105-117, 2000.

[5] J. Ratvio, "Ultralujan betonin kayttosovellukset Esitutkimus (preliminary study of ultra strength concrete applications)," VTT Tiedotteita, vol. 2078, pp. 3-45, 2001.

[6] C. T. Liu and J. S. Huang, "Fire performance of highly flowable reactive powder concrete," Construction and Building Materials, vol. 23, no. 5, pp. 2072-2079, 2009.

[7] G. F. Peng, Evaluation of fire damage to high performance concrete, Ph.D. thesis, Department of Civil and Structural Engineering, The Hong Kong Polytechnic University, Hong Kong, 2000.

[8] G. F. Peng, W. W. Yang, J. Zhao, Y. F. Liu, S. H. Bian, and L. H. Zhao, "Explosive spalling and residual mechanical properties of fiber-toughened high-performance concrete subjected to high temperatures," Cement and Concrete Research, vol. 36, no. 4, pp. 723-727, 2006.

[9] China Standard, 'GBJ 81-85 Method for testing mechanical properties of normal concrete', Beijing, China, 1985.

[10] International Union of Testing and Research Laboratories for Materials and Structures, "FMC1 determination of the fracture energy of mortar and concrete by means of threepoint bend tests on notched beams," in RILEM Technical Recommendations for the Testing and Use of Construction Materials, pp. 99-101, E \& FN SPON', London, UK, 1994.

[11] Y. N. S. Chan, G. F. Peng, and M. Anson, "Residual strength and pore structure of high-strength concrete and normal strength concrete after exposure to high temperatures," Cement and Concrete Composites, vol. 21, no. 1, pp. 23-27, 1999. 

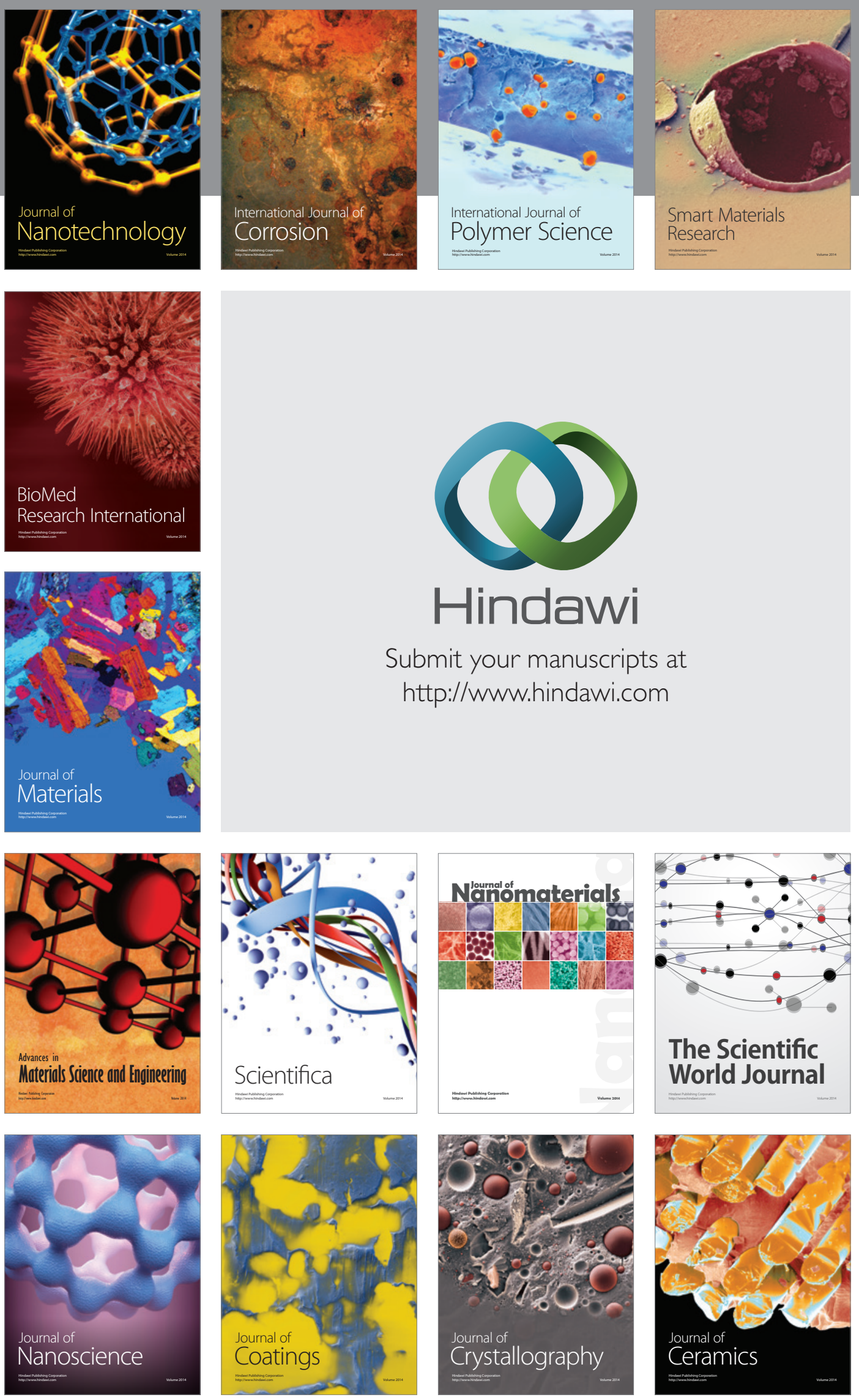

The Scientific World Journal

Submit your manuscripts at

http://www.hindawi.com

\section{World Journal}

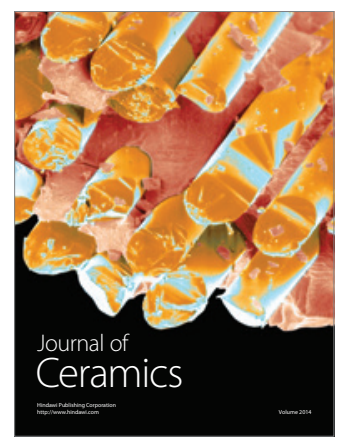

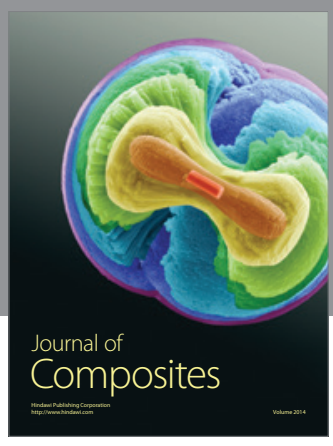
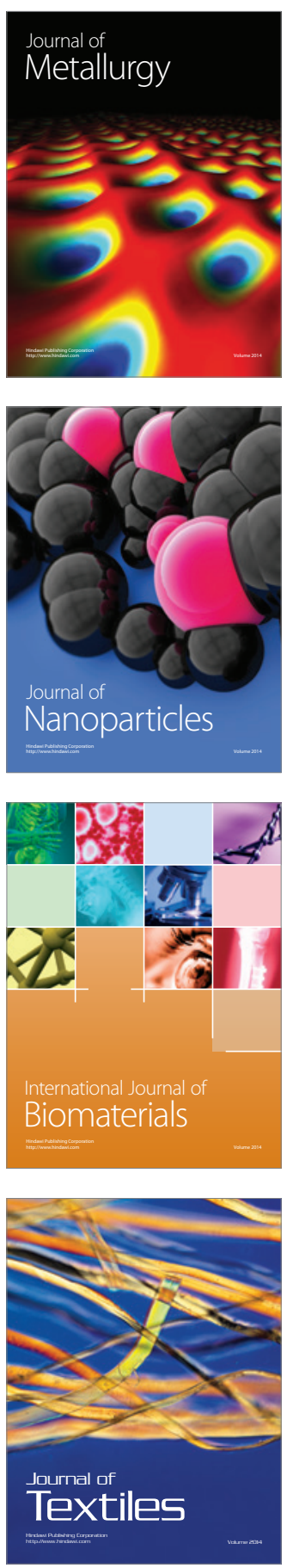